\title{
NADZÓR WŁAŚCICIELSKI NAD PRZEDSIĘBIORSTWAMI Z UDZIAÆEM SKARBU PAŃSTWA W KOREI POÆUDNIOWEJ I SINGAPURZE W KONTEKŚCIE DYSKUSJI DOTYCZĄCEJ REFORMY SYSTEMU NADZORU WŁAŚCICIELSKIEGO W POLSCE
}

\section{Wprowadzenie}

W gospodarkach kapitalistycznych, w których dominującą zasadę stanowi własność prywatna, istnieją też przedsiębiorstwa będące własnością państwa. Stosunek do tej formy własności różni się w zależności od realizowanej polityki. Rządy liberalne dążą do zmniejszania liczby przedsiębiorstw znajdujących się w domenie państwowej, z kolei rządy etatystyczne wykorzystuja je jako element polityki gospodarczej państwa. Istnieje obszerna literatura opisująca zagrożenia związane z funkcjonowaniem przedsiębiorstw kontrolowanych przez państwo. Nie zmienia to faktu, że opisywana grupa przedsiębiorstw jest obecna praktycznie na całym świecie.

W Polsce jako kraju postsocjalistycznym ma ona szczególnie duże znaczenie, ponieważ sektor przedsiębiorstw kontrolowanych przez Skarb Państwa został odziedziczony po gospodarce centralnie planowanej, która funkcjonowała w naszym kraju do końca lat 80. Transformacja systemowa i związane z nia procesy prywatyzacyjne znacząco zmniejszyły zakres domeny państwowej, jednakże z czasem zostały one zahamowane. W ostatnich latach można zaobserwować wzrost znaczenia własności państwowej oraz próby znalezienia nowego sposobu organizowania tej własności. Po wyborach w 2015 r. pojawiła się wola polityczna do przeprowadzenia strukturalnych zmian w uformowanym wcześniej systemie nadzoru właścicielskiego nad przedsiębiorstwami kontrolowanymi przez Skarb Państwa. Rozważane były pomysły implementacji rozwiązań azjatyckich, przede wszystkim koreańskich, i stworzenia holdingu złożonego z podmiotów zależnych od Skarbu Państwa. W 2017 r. wdrożono inne rozwiązanie - zlikwidowano Ministerstwo Skarbu Państwa, a nadzór nad majątkiem powierzono sektorowym ministrom. Ten system utrzymał się tylko 2 lata. W roku 2019 utworzono Ministerstwo Aktywów Państwowych (zbliżone do wcześniej funkcjonującego MSP) i zapowiedziano dalsze zmiany systemu nadzoru.

ORCID: 0000-0002-8480-6049, DOI: 10.4467/23538724GS.21.014.14846 
Biorąc pod uwagę zapowiedź kolejnych przekształceń systemu nadzoru nad przedsiębiorstwami z udziałem Skarbu Państwa w Polsce, wydaje się zasadne poddanie analizie wybranych modeli funkcjonujących w rozwiniętych krajach Azji. Zgodnie z postawioną w niniejszym artykule tezą system nadzoru właścicielskiego funkcjonujący w Singapurze jest lepszym wzorem dla ewentualnych planów utworzenia w Polsce holdingu spółek Skarbu Państwa niż system funkcjonujący w Korei Południowej. Z kolei celem artykułu jest przybliżenie systemu nadzoru właścicielskiego w Korei Południowej i Singapurze. Kraje te zostały wybrane, ponieważ w polskiej debacie publicznej mylnie utożsamia się system nadzoru właścicielskiego w Korei z modelem holdingowym, a zarazem niewystarczająca uwagę poświęca się systemowi w Singapurze, gdzie z powodzeniem wprowadzono takie rozwiązanie.

\section{Polityka właścicielska państwa}

Jednym z wyzwań polityki gospodarczej państwa jest wybranie odpowiedniego miksu własności prywatnej i państwowej. W gospodarkach krajów kapitalistycznych niewątpliwie przeważa własność prywatna. Cechuje ją większa efektywność wykorzystania czynników wytwórczych, ponieważ właściciel prywatny, kierujący się osobistym zyskiem ma najlepszą motywację, aby minimalizować koszty i maksymalizować korzyści. Z tej perspektywy każda własność publiczna (komunalna czy państwowa) musi prowadzić do mniejszej efektywności wykorzystania zasobów1. Przystępnie wytłumaczył to zjawisko Milton Friedman, zwracając uwage, że najlepiej wydawane są własne pieniądze na własne potrzeby, a najgorzej cudze pieniądze na cudze potrzeby ${ }^{2}$. Istnieja jednak sytuacje, które wymagają interwencji państwa, takie jak potrzeba zapewnienia powszechnego dostępu do dóbr i usług publicznych, występowanie negatywnych efektów zewnętrznych czy naturalnych monopoli³ Własność państwowa jest jednym ze sposobów rozwiązywania problemów związanych z niedoskonałościami rynku.

Działania państwa dotyczące posiadanej przez nie własności są nazywane polityka właścicielską. Piotr Kozarzewski definiuje ja jako „dziedzinę polityki gospodarczej, dotycząca wykonywania przez państwo lub podmioty od niego zależne pełnej wiązki uprawnień właścicielskich (posiadanie, korzystanie oraz rozporządzanie, $\mathrm{w}$ tym zbycie i nabycie własności)"4. Politykę właścicielską w tym ujęciu można podzielić na dwie części5: politykę przekształceń własnościowych i politykę nadzoru korporacyjnego.

1 Z. Staniek, Ekonomia instytucjonalna. Dlaczego instytucje sq wažne, Warszawa 2017, s. 119-120.

2 M. Friedman, R. Freidman, Wolny wybór, tłum. J. Kwaśniewski, Sosnowiec 2009, s. 128.

3 Corporate Governance of State-Owned Enterprises. A Survey of OECD Countries, Paris 2005, s. 21.

4 P. Kozarzewski, Polityka właścicielska państwa w okeresie transformacji systemowej: próba synteryy, Lublin 2019, s. 21.

5 Ibidem, s. 27-28. 
Polityka przekształceń własnościowych to działania mające na celu zmianę struktury własnościowej w gospodarce, co w pewnym uproszczeniu można utożsamiać ze zmianą liczby przedsiębiorstw znajdujących się w domenie państwowej. Rozróżnia się dwa kierunki przekształceń: prywatyzację i nacjonalizację. Prywatyzacja oznacza „przejmowanie praw (z reguły własnościowych) do majątku przedsiębiorstw państwowych przez podmioty prywatne". Analogicznie, nacjonalizacja to przejmowanie praw własnościowych do majątku przedsiębiorstw prywatnych przez podmioty państwowe. Z kolei polityka nadzoru korporacyjnego to całość działań dotyczących przedsiębiorstw, które pozostają w sferze dominium państwa. Jej celem jest stworzenie warunków potrzebnych do ich właściwego funkcjonowania i realizacji zadań. Ważnym elementem tej polityki jest nadzór właścicielski.

\section{Modele nadzoru właścicielskiego}

Organizacja Współpracy Gospodarczej i Rozwoju (ang. Organisation for Economic Cooperation and Development, OECD) ma duże doświadczenie w prowadzeniu badań nad nadzorem korporacyjnym w krajach członkowskich, zarówno w zakresie przedsiębiorstw prywatnych, jak i państwowych. W 2005 r. ukazały się Wyytyczne OECD dotyczqce nadzoru korporacyjnego w przedsięiorstwach publicznych ${ }^{7}$, które są ważnym punktem odniesienia w debacie dotyczącej omawianego zagadnienia na świecie. Od tego czasu poczyniono duże postępy w obszarze badań porównawczych nad systemami nadzoru w różnych krajach. Zgodnie z metodologią OECD można wyróżnić trzy podstawowe modele nadzoru właścicielskiego: model zdecentralizowany, model dualny, model scentralizowany ${ }^{8}$.

Model zdecentralizowany jest tradycyjnym sposobem organizacji nadzoru właścicielskiego nad przedsiębiorstwami kontrolowanymi przez Skarb Państwa. Jeszcze do niedawna był najbardziej rozpowszechnioną formą sprawowania funkcji właścicielskiej państwa ${ }^{9}$. Polega on na podzieleniu uprawnień właścicielskich względem przedsiębiorstw znajdujących się $\mathrm{w}$ domenie państwowej pomiędzy różne organy administracji państwowej. Zazwyczaj są nimi ministerstwa regulujące dany sektor gospodarki, ponieważ mają one największą branżową wiedzę z danej dziedziny w obrębie administracji państwa. Pojawia się jednak poważne zagrożenie zatarcia granicy pomiędzy funkcją właścicielską i funkcją regulacyjną państwa ${ }^{10}$. W rezultacie

${ }^{6}$ K. Oplustil, M. Porzycki, Polityka wtaścicielska panstwa i prywatyzacja [w:] Instytucje gospodarki rynkowej, red. T. Włudyka, M. Smaga, Warszawa 2018, s. 436.

7 Wytyczne OECD dotyczace nadzoru korporacyjnego w przedsiebiorstwach publicznych, Paryż 2005.

8 Corporate Governance of State-Owned Enterprises. A Survey..., s. 42.

9 Ibidem, s. 43.

10 D. Aziewicz, Koncepcje reformy systemu nadzoru nad spótkami zudziatem Skarbu Państwa w Polsce, „Gospodarka Narodowa” 2020, t. 304, nr 4, s. 141. 
przedsiębiorstwa z udziałem Skarbu Państwa moga być traktowane jako narzędzia w polityce sektorowej, często ze szkodą dla ich mikroekonomicznej efektywności. Może wystapić również sytuacja odwrotna, to znaczy polityka sektorowa może zostać dostosowana do potrzeb lub możliwości danego przedsiębiorstwa ze stratą dla konkurencji. System, w którym własność państwowa znajduje się pod nadzorem wielu ministrów, tworzy też zagrożenie rozmycia odpowiedzialności oraz utrudnia ocenę polityki właścicielskiej przez parlament i opinię publiczną.

Jednym ze sposobów ograniczenia nieefektywności zdecentralizowanego systemu jest powołanie organu koordynującego, który ma za zadanie ujednolicenie zasad nadzoru prowadzonego przez ministerstwa. Może on być odpowiedzialny za wprowadzenie spójnego systemu sprawozdawczości lub pełnić funkcję doradcza. Dobrym przykładem takiego systemu jest nadzór właścicielski w Wielkiej Brytanii po roku 2003, czyli po powołaniu agencji Shereholder Executive, której uprawnienia względem większości przedsiębiorstw z domeny państwowej ograniczały się do doradzania ministerstwom formalnie odpowiedzialnym za nadzór ${ }^{11}$. Jeśli dwa organy administracji państwowej dzielą się uprawnieniami właścicielskimi, to mamy do czynienia z systemem dualnym. W klasycznej formie tego systemu dwa ministerstwa jednocześnie sprawują nadzór nad danym przedsiębiorstwem. Zdarza się również, że jednocześnie funkcjonują w państwie dwa systemy nadzoru właścicielskiego. Tak jest np. w Norwegii, gdzie komercyjnie zorientowane przedsiębiorstwa są objęte nadzorem Ministerstwa Handlu i Rybołówstwa, a przedsiębiorstwa realizujące misje publiczną są kontrolowane przez branżowe ministerstwa ${ }^{12}$. System dualny ogranicza część wad systemu zdecentralizowanego, grozi jednak rozmyciem odpowiedzialności pomiędzy dwoma podmiotami ${ }^{13}$. Ze względu na złożoność tego modelu jego skuteczność jest uzależniona od jakości jego wdrożenia i dopasowania struktury do wyzwań danego kraju ${ }^{14}$.

Model scentralizowany jest rozwiązaniem najbardziej promowanym przez OECD i najczęściej wybieranym kierunkiem reform nadzoru właścicielskiego w wielu krajach. Istota tego modelu polega na przekazaniu jednej instytucji całości uprawnień właścicielskich względem przedsiębiorstw kontrolowanych przez Skarb Państwa. Nie zawsze jednak występuje on w czystej formie ${ }^{15}$. Nierzadko akceptowana jest grupa wyjątków, które są objęte innymi zasadami nadzoru, tak jak miało to miejsce w Polsce w czasie funkcjonowania Ministerstwa Skarbu Państwa. Model scentralizowany

11 The Shareholder Executive and Public Sector Businesses, House of Commons Committee of Public Accounts, London 2007, s. 5.

12 L. Van den Berghe, R. Van Goethem, The Belgian State as a shareholder, [b.m.] 2014, s. 22.

13 M. Bałtowski, G. Kwiatkowski, Przedsiębiorstwa państwowe we wspótcæesnej gospodarce, Warszawa 2018, s. 76.

14 L. Van den Berghe, R. Van Goethem, The Belgian State..., s. 8.

15 Ownership and Governance of State-Owned Enterprises: A Compendium of National Practices, [b.m.] 2018, s. 32. 
pozwala oddzielić sferę imperium i dominium państwa oraz jednoznacznie zidentyfikować podmiot, który odpowiada za sprawowanie nadzoru ${ }^{16}$. Instytucją wykonująca uprawnienia właścicielskie w modelu scentralizowanym jest zazwyczaj ministerstwo, zdarza się jednak, że nadzór powierza się agencji lub holdingowi.

Ostatni przypadek jest szczególnie ważny z punktu widzenia niniejszych rozważań. Zdarza się, że rząd powołuje spółkę portfelową, której powierza akcje i udziały innych podmiotów znajdujących się w domenie państwowej ${ }^{17}$. Takie rozwiązanie jest nazywane „modelem holdingowym” i ma zapewnić większą niezależność od procesów politycznych w podejmowaniu decyzji właścicielskich oraz wymusić zachowania podobne do podmiotów prywatnych ${ }^{18}$. Elementy modelu holdingowego moga występować w modelu dualnym, jak np. w Finlandii, gdzie część przedsiębiorstw została oddana pod nadzór holdingu Solidium $\mathrm{Oy}^{19}$, lub w modelu scentralizowanym, w którym większość lub wszystkie przedsiębiorstwa są nadzorowane przez holding. Takie rozwiazanie jest stosowane w Singapurze ${ }^{20}$. Holdingi wykorzystuje się w celu poprawy efektywności mikroekonomicznej przedsiębiorstw państwowych oraz przeprowadzenia prywatyzacji. Jednak OECD wydaje się sceptyczne w stosunku do modelu holdingowego, ponieważ nie ma dowodów na jego efektywność ${ }^{21}$.

\section{Debata nad systemem nadzoru właścicielskiego}

W ostatnich kilkunastu latach można zaobserwować zahamowanie procesów prywatyzacyjnych i wzrost znaczenia nadzoru właścicielskiego. W wielu krajach była to reakcja państw na kryzys finansowy lub jego skutki. Przykładem takiej sytuacji jest powstanie spółki UKFI (ang. UK Financial Investments) w Wielkiej Brytanii ${ }^{22}$. Warto jednak zwrócić uwagę, że w niektórych krajach reformy nadzoru rozpoczęły się przed kryzysem. We Francji powołano agencję APE (fr. Agence des participations de l'État) już w 2004 r. ${ }^{23}$ W Polsce w latach 90. uwaga państwa koncentrowała się na polityce przekształceń własnościowych. Kiedy z czasem prywatyzacja zaczęła wyhamowywać, znaczenia nabrała polityka nadzoru korporacyjnego. Można mówić o pewnej ciagłości w zakresie modelu realizowanego w Polsce od początku transformacji do roku 2016. Wraz z wprowadzeniem przemian prorynkowych zaczął się

\footnotetext{
16 Wytyczne OECD..., s. 30.

17 F. Grzegorczyk, Przedsiębiorstwo publiczne kontrolowane przę.panstwo, Warszawa 2012, s. 155.

18 Corporate Governance of State-Owned Enterprises. A Survey..., s. 59.

19 L. Van den Berghe, R. Van Goethem, The Belgian State..., s. 13-14.

20 Ibidem, s. 25.

21 Corporate Governance of State-Owned Enterprises. A Survey..., s. 60.

22 UK Government Investments, UK Government Investments Limited Annual Report and Accounts 2017-18, [b.m.] 2018, s. 8.

23 Agence des participations de l'État Annual Report 2016-2017, Paris 2017, s. 18.
} 
kształtować scentralizowany system nadzoru (z istotna grupą wyjątków) ${ }^{24}$, jednakże już w latach 90. powszechna była świadomość jego dysfunkcji. Istotną próbą reformy był Narodowy Program Nadzoru Właścicielskiego opracowany w 2010 r. Bazował on na rozwiązaniach norweskich i zakładał znaczne zmniejszenie domeny państwowej oraz sformalizowanie zasad nadzoru nad małą grupa pozostałych. Po wyborach w 2011 r. zdecydowano się zrealizować odmienną koncepcję. Zakładała ona budowanie tzw. narodowych czempionów i aktywne zarządzanie własnością państwowa. Spółki Skarbu Państwa miały przecierać szlaki polskim prywatnym przedsiębiorstwom na rynkach zagranicznych ${ }^{25}$.

Prawdziwy zwrot dokonał się jednak po wyborach w 2015 r., kiedy podjęto decyzję o likwidacji Ministerstwa Skarbu Państwa i zainicjowano pracę nad alternatywnymi sposobami sprawowania nadzoru właścicielskiego. To właśnie wtedy w polskim dyskursie publicznym zintensyfikowały się odwołania do wzorców koreańskich. Ich zwolennikiem był Dawid Jackiewicz, minister Skarbu Państwa w latach 2015-2016, który postulował utworzenie holdingu na wzór koreańskich czeboli ${ }^{26}$. Rozważane były różne koncepcje: utworzenie kilku holdingów branżowych ${ }^{27}$, jednego dużego holdingu zarzadzającego spółkami dotychczas nadzorowanymi przez Ministerstwo Skarbu Państwa ${ }^{28}$, stworzenie holdingu pełniącego nadzór nad spółkami strategicznymi i przekazanie pozostałych w nadzór ministerstwom sektorowym ${ }^{29}$. Wśród korzyści wynikających z nowej organizacji nadzoru właścicielskiego wskazywano: zwiększenie dochodów budżetu państwa pochodzących z dywidendy, ograniczenie kosztów administracyjnych, poprawę jakości nadzoru (dzięki likwidacji Ministerstwa Skarbu Państwa) ${ }^{30}$, osiagnięcie efektów synergii pomiędzy spółkami wchodzącymi w skład holdingu ${ }^{31}$. Współpraca miała polegać m.in. na preferowaniu spółek należących do holdingu (kupowaniu biletów lotniczych u PLL LOT, zakładaniu kont bankowych w PKO BP) ${ }^{32}$.

24 P. Kozarzewski, Polityka wtaścicielska..., s. 183.

25 D. Aziewicz, Z. Gawlik, Skorzystamy na tym wszyscy, „Pomorski Przegląd Gospodarczy” 2014, nr 3, s. 19.

26 M. Mejssner, Polska jak Korea Poludniowa? PiS chce polskich koncernów narodowych, Onet Biznes, http://biznes.onet.pl/wiadomosci/energetyka/polska-jak-korea-poludniowa-pis-chce-polskich-koncernow-narodowych/qfeq6g (dostęp: 4.03.2021).

27 J. Paweł, Dawid Jackiewricz: Holding państwony dobry, bo dusin, ,Rzeczpospolita”, 7.08.2016, https:// www.rp.pl/Wywiady-i-opinie/308079919-Dawid-Jackiewicz-Holding-panstwowy-dobry-bo-duzy. html (dostęp: 4.03.2021).

28 W. Gadomski, Synergia Dawida Jackiewicza, Wyborcza.pl, 18.08.2016, https://wyborcza.pl/ 1,155290,20565871,synergia-dawida-jackiewicza.html (dostęp: 4.03.2021).

29 Strategia państwowego boldingu, „Rzeczpospolita”, 29.02.2016.

30 IAR, Holding zastapi Ministerstwo Skarbu Państwa, Business Insider, 26.06.2016, http://archiwum.businessinsider.com.pl/kraj/dawid-jackiewicz-holding-zastapi-ministerstwo-skarbu-panstwa/ pjdlcx (dostęp: 4.03.2021).

31 W. Gadomski, Synergia Dawida Jackiewicza...

32 Strategia państwowego holdingu... 
Ponownie zwyciężyła inna koncepcja. Ustawa z dnia 16 grudnia 2016 r. o zasadach zarządzania mieniem państwowym pozwoliła premierowi przekazywać kompetencje nadzorcze mocą rozporządzenia. W ten sposób powstał zdecentralizowany system nadzoru, który utrzymał się zaledwie 2 lata ${ }^{33}$. Po wyborach w $2019 \mathrm{r}$. powołano Ministerstwo Aktywów Państwowych i zapowiedziano dalsze prace nad docelowym systemem nadzoru właścicielskiego. Powrót do wizji budowy holdingów wzorowanych na koreańskich czebolach można dostrzec $\mathrm{w}$ akwizycjach prowadzonych w 2020 r. przez PKN Orlen (Energa, Lotos, Polska Press).

\section{Korea Południowa}

Rozważania dotyczące wdrożenia rozwiązań koreańskich w Polsce często koncentrują się wokół koreańskich konglomeratów handlowych nazywanych czebolami ${ }^{34}$. Zapewne autorzy tego porównania odnoszą się do międzygałęziowego charakteru działalności tych grup kapitałowych i postrzegaja go jako szansę, a nie zagrożenie. Pytanie, czy taką tezę można obronić, nie jest przedmiotem niniejszego artykułu, aczkolwiek wydaje się zasadne, żeby przybliżyć samą istotę czeboli, która bywa pomijana w krajowej debacie.

Słowo „czebol” wywodzi się od koreańskich słów chae ('bogactwo', 'powodzenie') i bol ('grupa') ${ }^{35}$, co można rozumieć jako „grupe gospodarczą” lub „zwiazzek finansowy". Pojęcie to dotyczy koreańskiej wersji zjawiska, które w krajach Dalekiego Wschodu jest dość popularne, mianowicie dużych grup kapitałowych, jakimi są np. japońskie keiretsu ${ }^{36}$. Specyfika rozwiązań koreańskich polega na tym, że opisywane holdingi sa kontrolowane przez rodziny i funkcjonuja zgodnie z logika klanową. Czebolem kieruje głowa rodziny, nazywana chongsu, a funkcję tę dziedziczy najstarszy $\operatorname{syn}^{37}$. Jest to możliwe, ponieważ czebole stanowią kapitał prywatny. W Fair Trade Act z Korei Południowej podano następującą definicję czebola: „grupa przedsiębiorstw, której działalność gospodarcza jest poddana kontroli konkretnej wskazanej osoby"38.

Czebole powstały po II wojnie światowej w efekcie wyprzedaży majątku japońskiego po zakończonej okupacji i odegrały ważną rolę w odbudowie gospodarki po

\footnotetext{
33 Szerzej zob. D. Aziewicz, Koncepije reformy...

34 M. Mejssner, Polska jak Korea Poludniowa...

35 D. Murillo, Y. Sung, Understanding Korean Capitalism: Chaebols and their Corporate Governance, 2013, s. 2, https://itemsweb.esade.edu/research/esadegeo/201309Chaebols_Murillo_Sung_EN.pdf (dostęp: 9.10.2021).

36 B. Drelich-Skulska, Regionaliẓm ekonomiczny Ażi Wschodniej: jedno spojrzenie - różne nymiary, Wrocław 2012, s. 121-124.

37 D. Murillo, Y. Sung, Understanding Korean Capitalism..., s. 7.

38 B. Drelich-Skulska, Regionalizm ekonomiczny..., s. 124.
} 
wojnie koreańskiej. Z uwagi na ich historię porównanie z japońskimi keiretsu wydaje się uzasadnione, choć można wskazać istotne różnice. Konglomeraty japońskie w mniejszym stopniu polegają na więzach krwi, a centralny element grupy stanowi zazwyczaj bank. Z kolei koreańskie czebole są bardziej zhierarchizowane i zależne od relacjiz rzą$\mathrm{dem}^{39}$. Państwo odgrywa dużą rolę w koordynacji działań czeboli. Od początku uznawano je za narodowe czempiony i traktowano jako przedłużenie polityki gospodarczej państwa. Korzystały one z zamówień publicznych i preferencyjnych sposobów finansowania. Warto zauważyć, że w Korei zarówno państwo wpływa na czebole, jak i odwrotnie, co tworzy niebezpieczny system powiązań polityczno-biznesowych ${ }^{40}$.

W literaturze wymienia się również inne wady czeboli. Logika holdingu z jednej strony skłania zależne przedsiębiorstwa do kupowania produktów od powiązanych podmiotów, zamiast wybierać najlepszą opcję na wolnym rynku. Z drugiej strony zdarzały się przypadki, że potrzeba utrzymania władzy przez chongsu kolidowała z ekonomiczną racjonalnością, to znaczy osłabiano przedsiębiorstwa będące częścią czebola, zakładając konkurencyjne przedsiębiorstwa, żeby utrzymać władzę w klanie ${ }^{41}$.

Należy zauważyć, że negatywny wpływ czeboli na państwo i gospodarkę udało się zminimalizować dzięki reformom podjętym w $1998 \mathrm{r}$. Zanim to nastąpiło, podporządkowanie gospodarki oligarchicznym interesom narodowych korporacji doprowadziło do poważnego kryzysu w 1997 r. Kiedy na skutek kryzysu konglomeraty zostały pozbawione dostępu do państwowej pomocy, pojawiło się widmo ich bankructwa ${ }^{42}$. Przeprowadzone wtedy reformy miały na celu m.in. zwiększenie transparentności czeboli i wprowadzenie zasad corporate governance ${ }^{43}$. Efekty tych reform uznaje się za jeden z czynników, które pomogły Korei Południowej przezwyciężyć światowy kryzys z 2008 r. i szybko powrócić na ścieżkę wzrostu gospodarczego ${ }^{44}$.

Niezależnie od czeboli w Korei Południowej funkcjonują również przedsiębiorstwa kontrolowane przez państwo w sposób własnościowy. One także powstały po II wojnie światowej i odegrały znaczącą rolę w industrializacji kraju po wojnie koreańskiej. Na wczesnym etapie budowy koreańskiej gospodarki przedsiębiorstwa państwowe były głównymi zakładami produkcyjnymi. Realizowały też usługi publiczne ${ }^{45}$.

\footnotetext{
39 D. Murillo, Y. Sung, Understanding Korean Capitalism..., s. 4.

40 P.-S. Lee, Economic Crisis and Chaebol Reform in Korea, „Discussion Paper” 2000, no. 14, s. 3.

41 D. Murillo, Y. Sung, Understanding Korean Capitalism..., s. 6.

42 Ibidem, s. 5.

43 J. Chang, Y.J. Cho, H.-H. Shin, The Change in Corporate Transparency of Korean Firms After the Asian Financial Crisis: an analysis using analysts' forecast data, „Corporate Governance: An International Review" 2007, vol. 15, no. 6, s. 1144.

${ }^{44}$ K. Chekan, Korea and the Great Recession: The Effects of Chaebol Reform on South Korea's Recovery from the 2008 Financial Crisis, „US-Korea Yearbook” 2010, s. 97, https://cupdf.com/document/2010-sais-us-korea-yearbook.html (dostęp: 2.10.2021).

45 J. Park, J. Kim, C.J. Kim, Is the management evaluation system of state-owned enterprises in The Republic of Korea a good tool for better performance?, „ADBI Working Paper Series” 2019, no. 1055, s. 1.
} 
Raport OECD Corporate Governance of State-Owned Enterprises. A Survey of OECD Countries z 2005 r. szczegółowo opisuje ówczesny system nadzoru właścicielskiego nad przedsiębiorstwami kontrolowanymi przez Skarb Państwa w Korei Południowej. Stanowił on przykład modelu dualnego, przy czym był wyjątkowo złożony. Przedsiębiorstwa podlegały pod resorty sektorowe i ogólnogospodarcze. System nadzoru funkcjonujący w Korei określono nawet jako system trialny, ponieważ uprawnienia nadzorcze zostały podzielone między trzy ministerstwa ${ }^{46}$. Sytuację tę przedstawiono na rysunku 1. Na walnym zebraniu akcjonariuszy Skarb Państwa był reprezentowany przez przedstawiciela Ministerstwa Finansów i Gospodarki lub właściwego dla danej branży ministerstwa sektorowego. Wykonawczych członków zarządu (ang. executive board members) mianowało ministerstwo sektorowe, a niewykonawczych (ang. nonexecutive board members) Ministerstwo Budżetu i Planowania. Dodatkowo to ostatnie było odpowiedzialne za audyt, przeprowadzany w konsultacji z Ministerstwem Finansów i Gospodarki.

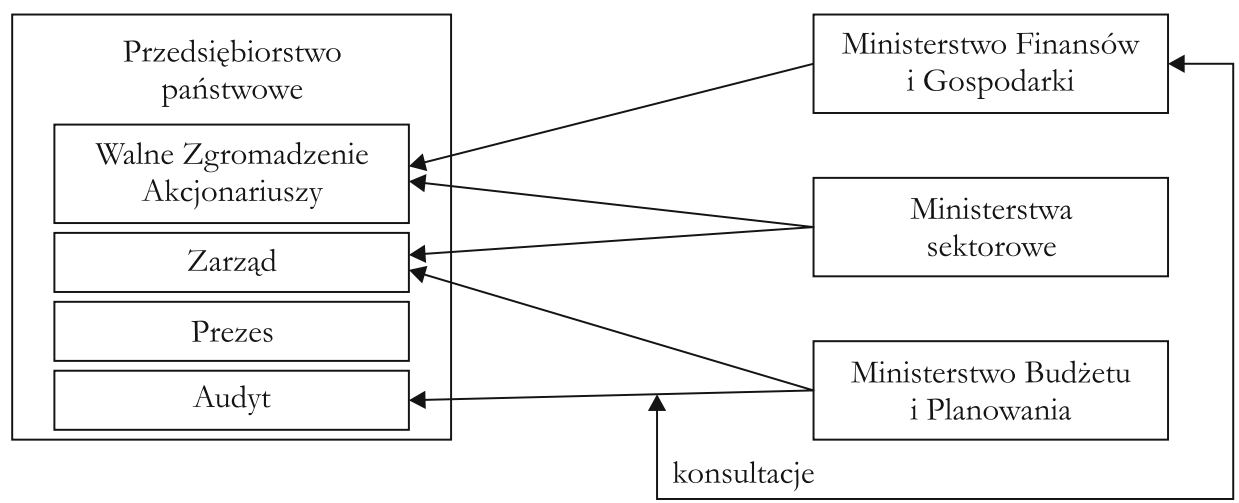

Rys. 1. Uprawnienia właścicielskie względem przedsiębiorstw państwowych w Korei Południowej w $2005 \mathrm{r}$.

Źródło: Corporate Governance of State-Owned Enterprises. A Survey of OECD Countries, Paris 2005.

System ten został znacząco uproszczony w 2007 r. Podjęto wtedy reformę, która miała jednoznacznie oddzielić funkcję właścicielską państwa od pozostałych obszarów działalności rządu ${ }^{47}$. W tym celu powołano Międzyresortowy Komitet Sterujacy pod przewodnictwem Ministerstwa Strategii i Finansów ${ }^{48}$. W Komitecie zasiadali zarówno przedstawiciele rządu, jak i niezależni eksperci. W nowym scentralizowanym systemie Ministerstwo Strategii i Finansów odpowiadało za prowadzenie

\footnotetext{
46 Corporate Governance of State-Owned Enterprises. A Survey..., s. 48.

47 W. Lee, Transparency of State-Owned Enterprises in South Korea, Washington 2014, s. 5.

48 Corporate Governance of State-Owned Enterprises. Change and reform in OECD countries since 2005, [b.m.] 2011, s. 16-17.
} 
polityki właścicielskiej, konsultując działania z pozostałymi resortami, tak aby zachować spójność z prowadzonymi przez nie politykami sektorowymi ${ }^{49}$.

W 2007 r. dokonano również podziału podmiotów znajdujących się w domenie państwowej na kategorie (tab. 1). Za przedsiębiorstwa państwowe uznano podmioty, które zatrudniaja przynajmniej 50 osób oraz same generują przynajmniej 50\% swoich przychodów. Wśród nich wyróżniono dwie grupy. Przedsiębiorstwa generujące powyżej 85\% swoich przychodów określono jako „rynkowe”, a te generujące między $50 \%$ a $85 \%$ jako „quasi-rynkowe” 50 . Warto zwrócić uwage na małą liczbę przedsiębiorstw państwowych w Korei. W roku 2017 było to 35 podmiotów (15 rynkowych i 20 quasi-rynkowych) $)^{51}$.

Tabela 1. Typy instytucji publicznych w Korei Południowej i najważniejsze kryteria ich podziału

\begin{tabular}{|l|l|}
\hline \multicolumn{1}{|c|}{ Klasyfikacja } & \multicolumn{1}{c|}{ Kryteria } \\
\hline $\begin{array}{l}\text { Przedsiębiorstwa państwowe } \\
\text { (ang. state owned enterprises) }\end{array}$ & $\begin{array}{l}\text { Liczba pracowników } \geq 50 \text { osób, } \\
\text { same generują } \geq 50 \% \text { przychodów }\end{array}$ \\
\hline $\begin{array}{l}\text { Przedsiębiorstwa państwowe rynkowe } \\
\text { (ang. market type) }\end{array}$ & $\begin{array}{l}\text { Liczba pracowników } \geq 50 \text { osób, } \\
\text { same generują } \geq 85 \% \text { przychodów }\end{array}$ \\
\hline $\begin{array}{l}\text { Przedsiębiorstwa państwowe quasi-rynkowe } \\
\text { (ang. quasi-market-based) }\end{array}$ & $\begin{array}{l}\text { Liczba pracowników } \geq 50 \text { osób, } \\
\text { generują 50-85\% przychodów }\end{array}$ \\
\hline $\begin{array}{l}\text { Przedsiębiorstwa quasi-rządowe instytucje } \\
\text { (ang. quasi-governmental institution) }\end{array}$ & $\begin{array}{l}\text { Liczba pracowników } \geq 50 \text { osób, } \\
\text { same generują }<50 \% \text { przychodów }\end{array}$ \\
\hline Inne instytucje publiczne & - \\
\hline
\end{tabular}

Źródło: Governance, Performance, and the Best Reform Practices in State-Owned Enterprises in Latin America and the Caribbean and Korea: Forum Report and Proceedings from the International Symposium beld Novem, Inter American Development Bank, 2015.

\section{Singapur}

Zdecydowanie bliższy pomysłom rozważanym w Polsce w latach 2015-2016 jest model nadzoru właścicielskiego nad przedsiębiorstwami kontrolowanymi przez Skarb Państwa w Singapurze. Funkcjonujące tam przedsiębiorstwa państwowe sa nazywane GLC (ang. government-linked companies) ${ }^{52}$. Nadzór nad nimi jest zorganizo-

49 W. Lee, Transparency..., s. 5.

50 Governance, Performance, and the Best Reform Practices in State-Owned Enterprises in Latin America and the Caribbean and Korea: Forum Report and Proceedings from the International Symposium held Novem, Inter American Development Bank, 2015, s. 15-16.

51 E. Ginting, K. Naqvi, Reforms, Opportunities, and Challenges for State-Owned Enterprises, Manila 2020, s. 48.

52 C.J. Milhaupt, M. Pargendler, Governance Challenges of Listed State-Owned Enterprises around the World: National Experiences and a Framework for Reform, „ECGI Working Paper” 2017, no. 352, s. 39. 
wany w formie prostego modelu holdingowego - Ministerstwo Finansów nadzoruje holding o nazwie Temasek, a on sprawuje nadzór nad przedsiębiorstwami, których akcje posiada ${ }^{53}$. Model ten przedstawiono na rysunku 2.

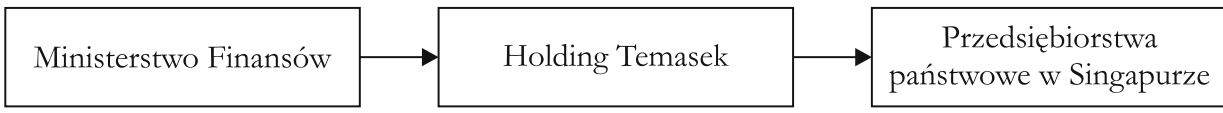

Rys. 2. Nadzór właścicielski nad przedsiębiorstwami z udziałem Skarbu Państwa w Singapurze Źródło: Opracowanie własne.

Temasek został utworzony w 1974 r. i podobnie jak koreańskie czebole odegrał istotną rolę w transformacji gospodarki ${ }^{54}$. Singapur, w przeciwieństwie do Republiki Korei, był zorientowany nie na rynek wewnętrzny, ale na handel zagraniczny, co wydaje się oczywiste, biorąc pod uwagę wielkość obu krajów. Singapurski system nadzoru jest uważany za wzór tego typu rozwiązania, a od innych zastosowań modelu holdingowego wyróżniają go dwie cechy: koncentracja na celach komercyjnych i znaczna niezależność od wpływów politycznych ${ }^{55}$.

Tesamek Holding podejmuje decyzje na podstawie przesłanek czysto komercyjnych. Nie ma obowiązku realizacji misji publicznej, co z jednej strony przekłada się na wysokie stopy zwrotu holdingu, a z drugiej budzi pewne watpliwości. Zapewne w mieście-państwie Singapurze łatwiej jest sprostać takim wymogom niż w Republice Korei czy Polsce. Nie pojawia się problem np. dostępu do usług pocztowych na terenie całego kraju. Jednak jeśli cele przedsiębiorstw mają charakter czysto komercyjny, powstaje pytanie, co uzasadnia własnościową interwencję państwa w gospodarkę. Zapewne jedna z odpowiedzi to zasilanie budżetu państwa poprzez dywidendę. Priorytetem holdingu jest generowanie zysku w długim okresie ${ }^{56}$.

Bardzo ciekawe sa zabezpieczenia przed interwencja państwa w decyzje holdingu. Minister finansów pełni funkcję właściciela w imieniu państwa, ale nie ma pełnej wiązki praw własności. Jego uprawnienia względem holdingu są ograniczone przepisami prawnymi, w tym konstytucją. Niektóre decyzje wymagają też zgody prezydenta Singapuru. Organy państwa nie wpływają na decyzje inwestycyjne holdingu. Wyjątek stanowi sytuacja, w której doszłoby do wykorzystania rezerw zgromadzonych przed aktualną kadencją rządu. Taką decyzję musi zatwierdzić prezydent ${ }^{57}$. Ograniczone są również uprawnienia państwa względem nominowania władz holdingu. Decyzje kadrowe dotyczące rady dyrektorów, które podejmuje minister

53 L. Van den Berghe, R. Van Goethem, The Belgian State..., s. 25.

54 www.temasek.com.sg (dostęp: 8.03.2021).

55 C.J. Milhaupt, M. Pargendler, Governance Challenges..., s. 40.

56 L. Van den Berghe, R. Van Goethem, The Belgian State..., s. 26.

57 www.temasek.com.sg (dostęp: 8.03.2021). 
finansów, muszą być zatwierdzane przez prezydenta Singapuru. Ponadto państwo nie decyduje o wysokości wypłacanej dywidendy ${ }^{58}$. Istnieja jednak pewne przesłanki sugerujące, że państwo nieformalnie wpływa na holding. W 2002 r. funkcja CEO została powierzona Ho Ching, żonie polityka Lee Hsiena Loonga, który w latach 1990-2004 był wicepremierem Singapuru. Jest on też najstarszym synem pierwszego premiera Singapuru Lee Kuana Yewy ${ }^{59}$.

Wartość portfolio holdingu wynosi 306 mld SGD. Największą wartość ma przedsiębiorstwo telekomunikacyjne Singapore Telecommunications Limited (7\% całości), następnie przedsiębiorstwo inwestycyjne i deweloperskie Mapletree Investments Pte Ltd (5\%) oraz DBS Group Holding (5\%) działające w branży finansowej ${ }^{60}$. W tabeli 2 zaprezentowano podział całego portfolio ze względu na branże. Jak widać, największy udział mają inwestycje w usługi finansowe i branżę telekomunikacyjna. Na kolejnych pozycjach uplasowały się nieruchomości oraz transport wraz z przemysłem, których wartość stanowi po 16-18\% portfolio. W ostatnich latach podwoił się udział inwestycji w nauki przyrodnicze i agrobiznes.

Tabela 2. Portfolio holdingu Temasek, udział procentowy poszczególnych branż ze względu na wartość aktywów bazowych w latach 2016-2020

\begin{tabular}{|l|c|c|c|c|c|}
\hline \multicolumn{1}{|c|}{ Branże } & $\mathbf{2 0 2 0}$ & $\mathbf{2 0 1 9}$ & $\mathbf{2 0 1 8}$ & $\mathbf{2 0 1 7}$ & $\mathbf{2 0 1 6}$ \\
\hline Usługi finansowe & 23 & 25 & 26 & 25 & 23 \\
\hline Telekomunikacja, media i technologia & 21 & 20 & 21 & 23 & 25 \\
\hline Nieruchomości & 17 & 17 & 16 & 17 & 17 \\
\hline Transport i przemysł & 16 & 16 & 16 & 17 & 18 \\
\hline Nauki przyrodnicze i agrobiznes & 8 & 7 & 6 & 4 & 4 \\
\hline Energia i zasoby & 2 & 3 & 3 & 3 & 3 \\
\hline Fundusze wielobranżowe & 8 & 8 & 8 & 8 & 7 \\
\hline Inne & 5 & 4 & 4 & 3 & 3 \\
\hline
\end{tabular}

Źródło: www.temasek.com.sg (dostęp: 8.03.2021).

Warto zwrócić uwagę, że duża część działalności holdingu odbywa się poza granicami kraju. W tabeli 3 przedstawiono zaangażowanie Temaseka w różnych regionach geograficznych. Podziału dokonano ze względu na wartość aktywów bazowych. Co ciekawe, znaczna ich część jest zainwestowana w Chinach, a w 2020 r. udział inwestycji w tym kraju był większy niż w Singapurze. Regularnie rośnie też udział inwestycji w innych krajach Azji Wschodniej. Zaangażowanie w pozostałych regionach wydaje się stabilne, z wyjątkiem Australii i Nowej Zelandii, gdzie w ciagu ostatnich 5 lat spadło prawie o połowę.

\footnotetext{
58 C.J. Milhaupt, M. Pargendler, Governance Challenges..., s. 41.

59 Ibidem, s. 42.

${ }^{60}$ www.temasek.com.sg (dostęp: 8.03.2021).
} 
Tabela 3. Portfolio holdingu Temasek, udział procentowy poszczególnych regionów geograficznych ze względu na wartość aktywów bazowych w latach 2016-2020

\begin{tabular}{|l|c|c|c|c|c|}
\hline \multicolumn{1}{|c|}{ Regiony } & $\mathbf{2 0 2 0}$ & $\mathbf{2 0 1 9}$ & $\mathbf{2 0 1 8}$ & $\mathbf{2 0 1 7}$ & $\mathbf{2 0 1 6}$ \\
\hline Chiny & 29 & 26 & 26 & 25 & 25 \\
\hline Singapur & 24 & 26 & 27 & 29 & 29 \\
\hline pozostałe kraje Azji Wschodniej & 17 & 15 & 13 & 12 & 10 \\
\hline Europa & 13 & 15 & 15 & 14 & 15 \\
\hline Australia i Nowa Zelandia & 5 & 6 & 7 & 8 & 9 \\
\hline Afryka, Centralna Azja i Bliski Wschód & 1 & 2 & 2 & 2 & 2 \\
\hline Ameryka Lacińska & 1 & 1 & 1 & 2 & 2 \\
\hline Inne & 10 & 9 & 9 & 8 & 8 \\
\hline
\end{tabular}

Źródło: www.temasek.com.sg (dostęp: 8.03.2021).

\section{Podsumowanie}

Koreański system nadzoru właścicielskiego jest daleki od stereotypów obecnych w polskiej debacie publicznej. Dla ewentualnego zorganizowania w Polsce systemu nadzoru właścicielskiego w formie holdingu zdecydowanie lepszym wzorcem okazuje się system singapurski niż koreański. Głównym argumentem jest fakt, że przedsiębiorstwa państwowe w Korei Południowej nie są zorganizowane w jeden holding. W przeszłości funkcjonował tam skomplikowany model trialny, w którym uprawnienia właścicielskie były podzielone między różne ministerstwa. W roku 2007 został on przekształcony w model scentralizowany, podobny do tego, który funkcjonował w Polsce do 2016 r. Warto zwrócić uwagę, że przedsiębiorstw znajdujących się w domenie państwowej jest w Republice Korei zdecydowanie mniej niż w Polsce. Również sposób zorganizowania czeboli wydaje się daleki od wyobrażeń obecnych w polskiej debacie publicznej. Przede wszystkim są to grupy kapitałowe kontrolowane przez rodziny i klanowy sposób myślenia stanowi istotę czebola. Warto również mieć na uwadze doświadczenie koreańskie, które uczy, że oligarchiczna władza właścicieli międzygałęziowych holdingów może mieć korupcyjny wpływ na państwo.

Niewątpliwie jako bardziej obiecujący prezentuje się model singapurski, gdzie przedsiębiorstwa państwowe zostały przekazane państwowemu holdingowi o nazwie Temasek. Jego zaletą jest m.in. stworzenie instytucjonalnych barier dla wpływu polityków na bieżące decyzje holdingu. Warto jednak zadać pytanie, czy państwo powinno utrzymywać własność w holdingu, który pozostaje w pełni komercyjny. Poza tym należy pamiętać, że w kraju o powierzchni Singapuru dostęp do dóbr i usług publicznych jest zdecydowanie łatwiejszy, a w Polsce argumenty o równym 
dostępie do usług i bezpieczeństwie energetycznym stanowią ciagle główne argumenty za utrzymywaniem własności państwowej.

Co za tym idzie, wzorce rozwiniętych krajów azjatyckich mogą stanowić punkt odniesienia, ale w ocenie autora nie powinny być kopiowane bezpośrednio. Zarazem odnosząc się do tych modeli, decydenci powinni być świadomi kontekstu historyczno-instytucjonalnego, w którym rozwiązania te powstały, i wyzwań, na które stanowiły odpowiedź.

\section{Literatura}

Agence des participations de l'État Annual Report 2016-2017, Paris 2017.

Aziewicz D., Koncepcje reformy systemu nadz̧oru nad spótkami zudziatem Skarbu Państwa w Polsce, „Gospodarka Narodowa" 2020, t. 304, nr 4.

Aziewicz D., Gawlik Z., Skorzystamy na tym wsæyssy, „Pomorski Przegląd Gospodarczy” 2014, nr 3.

Bałtowski M., Kwiatkowski G., Præedsiębiorstwa państwowe we wspótcæesnej gospodarce, Warszawa 2018. Berghe L. Van den, Goethem R. Van, The Belgian State as a shareholder, [b.m.] 2014.

Chang J., Cho Y.J., Shin H.-H., The Change in Corporate Transparency of Korean Firms After the Asian Financial Crisis: an analysis using analysts' forecast data, „Corporate Governance: An International Review" 2007, vol. 15, no. 6.

Chekan K., Korea and the Great Recession: The Effects of Chaebol Reform on South Korea's Recovery from the 2008 Financial Crisis, „US-Korea Yearbook” 2010, https://cupdf.com/document/2010-sais-us-korea-yearbook.html (dostęp: 2.10.2021).

Corporate Governance of State-Owned Enterprises. Change and reform in OECD countries since 2005, [b.m.] 2011.

Corporate Governance of State-Owned Enterprises. A Survey of OECD Countries, Paris 2005.

Drelich-Skulska B., Regionalizm ekonomiczny Azji W schodniej:jedno spojrženie - różne nymiary, Wrocław 2012.

Friedman M., Freidman R., Wolny mybór, tłum. J. Kwaśniewski, Sosnowiec 2009.

Gadomski W., Synergia Dawida Jackiewicza, Wyborcza.pl, 18.08.2016, https://wyborcza.pl/1,155 290,20565871,synergia-dawida-jackiewicza.html (dostęp: 4.03.2021).

Ginting E., Naqvi K., Reforms, Opportunities, and Challenges for State-Owned Enterprises, Manila 2020.

Governance, Performance, and the Best Reform Practices in State-Owned Enterprises in Latin America and the Caribbean and Korea: Forum Report and Proceedings from the International Symposium held Novem, Inter American Development Bank, 2015.

Grzegorczyk F., Pržedsiębiorstwo publiczne kontrolowane pržezpaństwo, Warszawa 2012.

IAR, Holding rastapi Ministerstwo Skarbu Panstwa, Business Insider, 26.06.2016, http://archiwum. businessinsider.com.pl/kraj/dawid-jackiewicz-holding-zastapi-ministerstwo-skarbu-panstwa/ pjdlcx (dostęp: 4.03.2021).

Kozarzewski P., Polityka właścicielska państwa w okresie transformaciji systemowej: próba syntę̧y, Lublin 2019.

Lee P.-S., Economic Crisis and Chaebol Reform in Korea, „Discussion Paper” 2000, no. 14.

Lee W., Transparency of State-Owned Enterprises in South Korea, Washington 2014.

Mejssner M., Polska jak. Korea Poludniowa? PiS chce polskich koncernów narodonych, Onet Biznes, http:// biznes.onet.pl/wiadomosci/energetyka/polska-jak-korea-poludniowa-pis-chce-polskich-koncernow-narodowych/qfeq6g (dostęp: 4.03.2021). 
Milhaupt C.J., Pargendler M., Governance Challenges of Listed State-Owned Enterprises around the World: National Experiences and a Framework for Reform, „ECGI Working Paper” 2017, no. 352.

Murillo D., Sung Y., Understanding Korean Capitalism: Chaebols and their Corporate Governance, 2013, s. 2, https://itemsweb.esade.edu/research/esadegeo/201309Chaebols_Murillo_Sung_EN.pdf (dostęp: 9.10.2021).

Oplustil K., Porzycki M., Polityka wtaścicielska państwa i prywatyzacja [w:] Instytucje gospodarki rynkowej, red. T. Włudyka, M. Smaga, Warszawa 2018.

Ownership and Governance of State-Owned Enterprises: A Compendium of National Practices, [b.m.] 2018. Park J., Kim J., Kim C.J., Is the management evaluation system of state-owned enterprises in The Republic of Korea a good tool for better performance?, „ADBI Working Paper Series” 2019, no. 1055.

Paweł J., Dawid Jackiewic飞: Holding państwowy dobry, bo dušy, „Rzeczpospolita”, 7.08.2016, https:// www.rp.pl/Wywiady-i-opinie/308079919-Dawid-Jackiewicz-Holding-panstwowy-dobry-bo-duzy.html (dostęp: 4.03.2021).

Staniek Z., Ekonomia instytucjonalna. Dlaczego instytucje sq wa:̧ne, Warszawa 2017.

Strategia państwowego holdingu, „Rzeczpospolita”, 29.02.2016.

The Shareholder Executive and Public Sector Businesses, House of Commons Committee of Public Accounts, London 2007.

UK Government Investments, UK Government Investments Limited Annual Report and Accounts 201718, [b.m.] 2018.

Wytyczne OECD dotyczqce nadzoru korporacyjnego w przedsiębiorstwach publicznych, Paryż 2005.

\section{SUMMARY}

\section{STATE-OWNED ENTERPRISES SUPERVISION SYSTEM IN SOUTH KOREA AND SINGAPORE, WITHIN THE CONTEXT OF THE DEBATE ABOUT REFORMING STATE-OWNED ENTERPRISES SUPERVISION SYSTEM IN POLAND}

State-owned enterprises are a part of most modern economies. Therefore, it is substantial to elaborate which model of supervision system is the most suitable for the challenges of each country. Since the 2015 there is an ongoing debate in Poland, about the shape of a stateowned enterprises supervision system. It was considered to establish a national holding company, which would perform the ownership function for Polish state-owned enterprises. An inspiration for this idea was the South Korean state-owned supervision system and the impact of the chaebols on the Korean national economy. The aim of this article it to examine Korean solutions, and to present the state-owned supervision system which function in Singapore, because in many ways it seems to be a more adequate inspiration for the needs of Polish decision-makers. 